and Amersham, from which radioactive effluents are discharged. These liquors, in which the level of activity permitted is very low, aro regularly monitored before being released-the Harwell effluent by the Atomic Encrgy Authority, the Ministry of Housing and Local Government, and the Metropolitan Water Board. There is no evidence, from the Board's observations, that there has ever been any activity present, at its raw water intakes, which could be attributed to discharges from the three establishments. The concentration of activity in treated water is about half that present (from fall-out) at the intakes, both in the Thames and Lee, the reduction being due to removal of suspended matter, radioactive decay during storage, and sometimes to dilution with relatively inactive well water. A large-scale experiment was made by adding 500 me. of strontium-90 to 1.5 million gallons of water, standing in a disused filter bed; during a period of nine months the level of activity was reduced by about two-thirds (the water contained abundant algae and much rooted vegetation), but the results suggested that grossly contaminated waters would not be rendered potable in any reasonable time by storage alone.

An examination of waters from a number of wells for the presence of alkylbenzene sulphonates-the anionic surface-active agents which are the basis of powdered synthetic detergents - showed that in some they were absent, but that in others they were present in concentrations similar to those found in the Thames to which sewage effluents are discharged. It is of great interest that in a well water the presence of the surface-active material may be the only surviving evidence that the water has beon polluted by sewage or sewage effluent-ammonia, coliform bacteria, and the other usually diagnostic constituents of effluents having been removed during percolation of the water through the ground. These observations were made before the use on a large scale of biologically 'softer' alkylbenzene sulphonates in detergents sold in the south of England.

Continuing its work on the relation between chemical structure and susceptibility to degradation by bacteria, a wide range of organic substances has now been examined in the Board's laboratories; from this the important conclusion is recched that because of the relative immunity of chlorine-substituted organic compounds to bacterial attack, it is unwise to chlorinate effluents containing mainly organic matter; this would include sewage effluents. Chlorination of such effluents has never been widely practised in Great Britain but appears to be common in the United States, and there has been a good deal of discussion recently on the wisdom of adopting this quite expensive method of treatment.

Among the other matters dealt with in the report are the use of automatic instruments for recording concentration of dissolved oxygen (a knowledge of which is important in taking a water supply from a thermally stratified reservoir); the presence of Salmonella organisms in bone meal and other fertilizers ; and the persistence of fluoride in water during storage in a reservoir. Considerable advances have been made in the use of the membrane filter technique in the counting of coliform bacteria; with this method the count is available after $18 \mathrm{hr}$. as against $24 \mathrm{hr}$. with the older multiple-tube technique.

B. A. Southg ATE

\title{
EAST AFRICAN FISHERIES RESEARCH ORGANIZATION
}

$\mathrm{T}$ the scientist the annual report for 1959 of the East African Fisheries Research Organization can only be a somewhat depressing document*. When the Jinja Laboratory was established in 1947-48 together with the Lake Victoria Fisheries Service, there seemed to be some real prospect of keeping a developing fishery under full observation, and managing it in a scientific manner in the light of both the catch statistics collected by the Fisheries Service and the information on the biology of the fish acquired by the staff of the Laboratory. In the eleven years of its life the Laboratory has not only made good progress with the task assigned to it, but also made notable contributions to our knowledge of tropical waters. On the other hand, those responsible for government at the political level have signally failed to profit by the scientifically based advice tendered by the Research Organization. As a result, the fishery is rapidly declining in productivity owing to overfishing, precisely as it was predicted that it would in the absence of more stringent and effective control. That this small fishery should be following the same downward path as the internationally exploited sea fisheries, where control is so much more difficult to exercise, is a sad reflexion not only on man's cupidity. but also on the lack of scientific understanding of so many of those we appoint to

* East Africa High Commission. East African Fisheries Research Organization: Annual Report 1959. Pp. ii +46. (Jinja: East African Fisheries Research Organization 1960.) govern us. This last point is further emphasized by the fact that in the small staff at Jinja (a director, four research officers and two senior field officers) there is a vacancy for a fifth research officer which cannot at present be filled for lack of finance. Consequently, the work of the Laboratory is now restricted almost entirely to fish, and moreover the Lake Victoria Fisheries Service has been disbanded, though its duties have been, at least nominally, transferred to the Fisheries Departments of the three Territories concerned (Kenya, Tanganyika and Uganda). It is much to be hoped that means will be found to continue the fundamental observations on the hydrography and chemistry, and the algal and invertebrate populations of the Lake, on which the Laboratory has made such an excellent start.

A series of appendixes give in a convenient, concise and readable form the results of some of the work done at the Laboratory during the year. One of these contains important observations on the analysis of data based on gill-net catches, made by a member of the staff of the Fisheries Laboratory at Lowestoft. Another shows how easily and rapidly the very local populations of Tilapia esculenta in Lake Victoria can be over-fished down to a level at which the yield ceases to be profitable. A third gives briefly the results of an investigation, made by an entomologist, of the food of several of the species of fish other than Cichlidae which inhabit Lake Victoria. In contrast to the mainly herbivorous species of Tilapia, the 
species of Alestes, Synodontis afro-fischeri and Marcusenius grahami eat mostly insects, whereas Barbus altianalis and Synodontis victoriae get most of their sustenance from snails. Other appendixes contain shorter notes on a variety of topies, including the growth of Tilapia zillii in a dam and some preliminary observations on the control by fish of snails and mosquitoes in dams.

The director, Mr. R. S. A. Beauchamp, who has recently relinquished the post he has held with distinction since he opened the Laboratory in 1948, can look back on a considerable achievement. Not only have he and his colleagues laid a firm foundation of knowledge of the hydrography, chemistry and biology of at least the parts of Lake Victoria within the reach of the Laboratory, but they have also made significant contributions, briefly described in the reports of which this is the latest, to our understanding of the factors which control the productivity of tropical waters. Moreover, the Laboratory itself now has a world-wide reputation and attracts visitors from many countries.

H. C. GILson

\section{U.S. MATERIALS RESEARCH AND DEVELOPMENT FOR NATIONAL SECURITY}

\begin{abstract}
A SPECIAL Committee on Scope and Conduct of Materials Research was appointed by $\mathrm{Dr}$. D. W. Bronk, president of the National Academy of Sciences, to review the materials research noeds of the United States with regard to national defence and the public welfare generally; to appraise the adequacy of the present research programmes to meet those needs; to consider the resources available ; and to make recommendations. A report now issued under the title "More Effective Organization and Administration of Materials Research and Development for National Security" deals with the scope of materials research from the point of view of the overall adequacy of the present effort, but leaves for continuing review by the Materials Advisory Board of the National Academy of Sciences-National Research Council the question of scope in regard to the technical content of the programme*. The question of scope in regard to the scientific content will be dealt with in a forthcoming report of the Academy-Research Council's Committee on Perspectives in Materials Research.

The Committee found that important national security programmes, particularly in defence, nuclear energy and space-research are impeded by the inadequacy of the properties of most of the materials now available to withstand the severe temperature,

- Tational Academy of Sciences-National Research Council. Publication No. 718: More Effective Organization and Administration of Materials Research and Development for National Security. (A Report to D. W. Bronk, President, National Academy of Sciences, by the Committee on Scope and Conduct of Materials Research.) Pp. ix +30 . (Washington, D.C.: National
\end{abstract}

pressure, radiation, corrosion and stress conditions involved and give high performance. The Committee recommends accordingly that the Government accord high priority in national security plans and programmes to the development of new and improved materials and that the relevant programmes of the agencies and departments be strengthened. Tho Committee recognizes that there is no simple solution, but that every level of activity needs significant strengthening. To this end it recommends greater centralization of responsibility, more support for, and more effective co-ordination of Governmentsponsored materials research and development programmes; Government incentives to encourage rosearch and development on new and improved materials; and steps to assure adequate supplies in the United States of every chemical element or material to support full production and use of new and improved materials. It also recommends improvement in the dissemination of research information and strengthening the universities in their dual role of training scientists and engineers and pursuing research. In regard to the last, the Committee endorses a recently announced programme of Government-sponsored interdisciplinary materials laboratories at several institutions of higher learning, while as regards the dissemination of information it envisages the encouragement and acceleration of publication and removal of secrecy restrictions as well as the greater support of research designed to encourage rapid exchange of technical and scientific information, including expansion and acceleration of the Critical Tables project.

\section{EDUCATION AND INDUSTRY}

$\mathrm{B}$ RITISH industry has traditionally been badly served by the universities and by the majority of schools. Until quite recently, they have encouraged very few of the ablest young people to think in terms of an industrial career.

The prejudice was not all on one side. The typical industrialist of not so long ago, while he was ready enough to concede the importance of craft training, and even of technical education, conceived rather narrowly, held that industry had certainly no responsibility for any but quite specialized courses, and that no useful purpose would be served by recruiting men on a basis of intellectual quality rather than skill.
Prof. D. G. Christopherson, in a recent issue of the Esso Magazine (Spring, 1960), suggests that, although these attitudes are changing, it is the attitude of industry which has changed most quickly and most completely in our time. Before the War, most professors of engineering spent their time resisting pressure from industry in the direction of making courses more specifically technical, so that the graduate would be better able to do a particular job immediately on joining the firm. To-day, the influence of industry is in the opposite direction. Professors of engineering are urged to keep courses general, to resist undue specialization, at least until 